\title{
Tax revenue, expenditure, and economic growth: An analysis of long-run relationships
}

\author{
NGUYEN PHUONG LIEN \\ Hoa Sen University - phuongliennguyen0601@gmail.com \\ SU DINH THANH \\ University of Economics HCMC - dinhthanh@ueh.edu.vn
}

\section{ARTICLE INFO ABSTRACT}

Article history:

Received:

Dec., 23, 2016

Received in revised form:

May, 15, 2017

Accepted:

June, 30, 2017

Keywords:

long-term economic growth, co-integration test, tax revenue and expenditure.
Focusing on the investigation of "long-term" relationship between tax revenue, expenditure, and economic growth, this paper employs the Granger causality test and finds that the linkage between tax revenue and spending is a bi-directional causal correlation. Furthermore, applying Persyn and Westerlund's (2008) co-integration test allows for corroboration of existence of long-run cointegration linkages among outcome of economy and the three variables. In addition, by adopting two-step system generalized method of moments (SGMM) for a dynamic panel of 82 developed and developing countries during 16-year period (2000-2015), this research demonstrates that the impact of tax revenue and spending is substantial and ambiguous, depending on different groups of economies. 


\section{Introduction}

It is widely known that any change in public policy can affect economic activities (Holley, 2011). During the last decades there have been numerous studies that investigated the linkage between public spending or tax revenue and economic growth. Dzhumashev (2014) revealed that relations among public finance, institutional quality, and economic growth are too ambiguous, which needs to be clarified.

Furthermore, despite Barro's (1990) argument that it is equal to public expenditure, tax revenue depends on public expenses. The question, therefore, is "how does tax revenue correlate closely with government expenditure?" In the past two decades, the results seem to be mixed and confusing.

In addition, through the statistics obtained of income per capita, tax revenue, and government expenditure, this research shows different trends of these variables by types of economic groups. While developed countries are likely to collect more taxes, spend less, and maintain the slow speed of growing outcome, developing countries keep spending more and collect less revenue for rapid growth in their economies (see appendix A). Moreover, a marked difference between developed and developing countries lies in the fact that developing countries constitute more than $60 \%$ of the world population, but they contribute less than 30\% to global GDP (Spence, 2011).

This paper initially attempts to investigate the causal correlation between tax revenue and government spending. The second objective is to evaluate long-run economic growth affected by tax revenue and government expenditure (hereafter termed "public finance factors"). Finally, it is imperative to estimate the level effects of tax revenue and expenditure on economic growth depending on kinds of groups of economies to expand the literature on endogenous economic growth.

Besides the introduction, this paper is structured as follows. The second section discusses the theoretical background and briefly describes previous research findings in the same field. Section 3 presents the empirical dataset and findings, followed by Section 4, which concludes the study and also draws a few implications.

\section{Theoretical bases, previous empirical research, and methodologies}

Relationship between tax revenue and government spending

The interaction between tax revenue and government spending can be divided into three strands. First, there is a fiscal synchronization hypothesis that confirms the bidirectional causal link between the two variables (Musgrave, 1966; Meltzer \& Richard, 1981; Bohn, 1991; Chang \& Chiang, 2009). Second, the "spend-tax" hypothesis, which maintains that government expenditure can be a root cause of change in tax revenue (Friedman, 1978; Darrat, 1998; Blackley, 1986). The last strand is reflected through "tax-spend" hypothesis that takes into account the role of 
tax revenue in enabling government to lead expenses (Mahdavi \& Westerlund, 2008; Hansan et al., 2012). However, most studies examined panel data of high income countries or of merely one country and arrived at main conclusions to justify the three listed hypotheses. For supporting government planners, a question can be posed as to whether there exists a bidirectional causality linkage between tax revenue and expenditure for both developed and developing countries.

To investigate this relationship, this study applies the causality theory suggested by Granger (1969) and sets out to examine the bidirectional causal linkage between tax revenue and government spending in the context of developed and developing countries. The null hypothesis can be formulated as follows:

$$
\begin{gathered}
H_{0}: \beta_{i}^{(k)}=\beta^{(k)} \forall_{i=1, \ldots \ldots N}, \forall_{k=1, \ldots ., p} \\
H_{1}: \beta_{i}^{(k)} \neq \beta_{j}^{(k)}, k \in\{1, \ldots, p\}, \exists(i, j) \\
\in\{1, \ldots ., N\}
\end{gathered}
$$

The corresponding $\mathrm{F}$ test is:

$$
Z=\frac{\left(S R R_{k}-S R R_{1}\right) / p(N-1)}{S R R_{1} /[N T-N(1+p)-p]}
$$

The empirical research equation for Granger test is computed as:

$$
\begin{aligned}
& \operatorname{taxrev}_{i, t}=\beta_{0}+\sum_{i=0}^{k} \beta_{1} g \exp _{i, t-1}+ \\
& \sum_{i=1}^{p} \delta_{1} \operatorname{taxrev}_{i, t-1}+\varepsilon_{i}+\vartheta_{i, t} \\
& \quad \operatorname{gexp}_{i, t}=\gamma_{0}+\sum_{i=0}^{k} \gamma_{1} \operatorname{taxrev}_{i, t-1}+ \\
& \sum_{i=1}^{p} \theta_{1} \operatorname{gexp}_{i, t-1}+\varepsilon_{i}+\vartheta_{i, t}
\end{aligned}
$$

where $\operatorname{taxrev}_{i, t}$ is the proportion of total tax revenue to gross domestic products (GDP) of country $\mathrm{i}(\mathrm{i}=1, \ldots \mathrm{N})$ at time $\mathrm{t}(\mathrm{t}=1, \ldots \mathrm{T})$, $\operatorname{gexp}_{i, t}$ denotes the proportion of total government expenditure to GDP, $\mathrm{k}$ and $\mathrm{p}$ are latencies, $\varepsilon_{i}$ stands for countrycharacteristic effects, and $\vartheta_{i, t}$ represents the observation error with $\mathrm{E}\left(\vartheta_{i, t}\right)=0$.

In addition, short-term tax changes can be different from long-run effects because of a great elasticity of demand curve (Holley, 2011). In the past decade there have been few studies performing a comprehensive analysis of this difference to help policy makers design the appropriate policies in public finance.

Since it helps avoid the bias given the case of regressions from nonstationary variables, multiple studies employed cointegration test to clear up the problem of spurious regression (e.g., McCoskey \& Kao, 1999; Bai \& Ng, 2004; Pedroni, 2004; Breitung \& Pesaran, 2005; Westerlund \& Edgerton, 2008; Persyn \& Westerlund, 2008).

The following question, therefore, should be determined: "Do cointegration relationships exist among tax revenue, government spending, and long-run economic growth?"

In addition, the error-correction (EC) model is often applied to investigate the long-run relationship between stationary as well as cointegrated variables (Ojede \& Yamarik, 2012).

Assuming that $i$ represents a country and $t$ is time period, the long-run relationship can be represented as below: 


$$
\operatorname{lrgdp} p_{i, t}=\alpha_{0, i}+\alpha_{i, t}^{\prime} X_{i, t}+u_{i, t}
$$

where $\operatorname{lrgdp} p_{i, t}$ is logarithm of real GDP per capita (dependent variable), $\alpha_{0, i}$ is a country-specific intercept term, $\alpha_{i, t}^{\prime}$ denotes country-characteristic slope coefficients, $X$ indicates the vector of public finance and institutional quality, and $u_{i, t}$ is an error term of country $i$ at time $t$.

In case a co-integration linkage exists between $\operatorname{lrg} d p_{i, t}$ and $X$ variables, and error term $u_{i, t}$ is an $\mathrm{I}(0)$ process for all countries $i$, we can re-write the growth equation in terms of an autoregressive distributed lag (ARDL) of order $(\mathrm{p}, \mathrm{q})$ as below:

$$
\begin{aligned}
& \quad \operatorname{lrgdp}_{i, t}=\beta_{1, i} \operatorname{lrgdp}_{i, t-1}+ \\
& \beta_{2, i} \operatorname{lrgd} p_{i, t-2}+\cdots+\beta_{p, s} \operatorname{lrg} d p_{i, t-p}+ \\
& \sigma_{0, i}^{\prime} X_{i, t}+\sigma_{1, i}^{\prime} X_{i, t-1}+\cdots+\sigma_{q, i}^{\prime} X_{i, t-q}+ \\
& \varepsilon_{i}+\vartheta_{i, t},
\end{aligned}
$$

where $p$ is number of lag of dependent variable, and $\mathrm{q}$ is number of lag of independent variables.

Then, we re-design the error-correction model as follows:

$$
\begin{gathered}
\Delta \operatorname{lrg} d p_{i, t}=\sum_{j=1}^{p-1} \beta_{j, i} \Delta \operatorname{lrg} d p_{i, t-j}+ \\
\sum_{j=0}^{q-1} \sigma_{j, i}^{\prime} \Delta X_{i, t-j}+\mu_{i}\left[\operatorname{lrg} d p_{i, t-1}-\theta_{0, i}-\right. \\
\left.\theta_{1, i}^{\prime} X_{i, t}\right]+\vartheta_{i, t}
\end{gathered}
$$

where $\beta_{j, i}$ and $\sigma_{j, t}$ are short-run coefficients, $\theta_{0, i}$ and $\theta_{1, i}$ stand for long-run coefficients, and $\mu_{i}$ represents an adjustment-speed (error-correction term) to the long-run equilibrium.

Definition of public finance and its effect on economic growth
As documented by Barro (1990), Buchanan (1999), Wellisch (2004), Kaul and Conceição (2006), and McGee (2013), tax revenue and expenditure are two major components of public finance. Barro (1990) explained the mode of interaction between government expenditure and taxes with their effects on household spending and income. Moreover, from Barro's (1990) perspective, there might be a too simple social regime, where government collects taxes from income and property only. The limitation of this research is that it does not evaluate the relationship between total tax revenue and total public spending, which articulates the government capability.

In the last decades, two stances have emerged in evaluating growth effect of tax revenue and government expenditure. First, a number of researchers used the endogenous growth model to estimate the impact of tax revenue or expenditure in isolation. Second, they applied the causality or cointegration test to capture the linkage between economic growth and tax structure or share of expenditure.

A few previous investigations indicated that income tax, sale tax, or property tax has full meaning in reducing economic outcome in both developing and developed economies (Lee \& Gordon, 2005; Ojede \& Yamarik, 2012; Amir et al., 2013, Adkisson $\&$ Mohammed, 2014). In addition, Bujang et al. (2013) employed Kao's cointegration test for a panel dataset of 24 developing and 24 developed countries in a 10-year period and mentioned that tax structure and GDP in developing countries do not have the longrun cointegrating linkages, but only in 
developed countries do these links exist. Furthermore, Easterly and Rebelo (1993) revealed that income tax increases economic growth, while custom tax reduces it.

Some earlier studies also showed the mixed growth effect of government spending and tax revenue. Barro (1991) performed an empirical study of 98 countries from 1960 to 1985 and noted that the relationship between public spending and economic growth is negative. Furthermore, Hitiris and Posnett (1992) analyzed the data of 20 OECD countries over a 28-year period, demonstrating that when government spends a certain amount on health care, this expense can promote income per capita. Applying OLS, fix effects, and pooled OLS techniques, Kneller et al. (1999) performed an analysis of the dataset of 22 developed countries between 1970 and 1995 and found that government spending positively affects income per capita, whilst taxation exerts a harmful effect on this variable. Cooray (2009) adopted the generalized method of moments to indicate that public spending and quality of governance positively affect economic growth. In addition, Dzhumashev (2014) argued that public expenditure depends on effectiveness of governance as well as level of corruption. How do tax revenue and expenditure afftect economic growth? Do their levels of effects differ considering different kinds of economic groups? The questions are to be tackled in the next sections of this study.

\section{Methodologies}

Before running co-integration test, this paper employs the unit root test following
HT (1999) and IPS (2003). The HarrisTzavalis (HT) (1999) test hypothesizes that all panels have the same autoregressive parameter and rho is smaller than 1. It also assumes that the periods of time are fixed, which is similar to the Levin-Lin-Chu test. However, the IPS test does not necessitate balanced data, but requires that $\mathrm{T}$ must be at least 5 , if the dataset is strongly balanced for the asymptotic normal distribution of Z-ttilde-bar to hold.

For co-integration test, this study follows Persyn and Westerlund's (2008) proposed technique, developed by Westerlund (2007). This allows for complete check of heterogeneous characteristics of long-run parts of error correction model. The null hypothesis is $\mathrm{H}_{0}: \mathrm{a}_{\mathrm{i}}=0$ for all $\mathrm{i},(\mathrm{i}=1, \ldots \mathrm{N})$ and H1: $: a_{i}<0$ for all $I,(i=1, \ldots N)$. This test uses the $G_{a}$ and $G_{t}$ test statistics for checking the null hypothesis for at least one $i$. These statistics start from a weighted average of the individually estimated $a_{i}$ 's and their $t-$ ratio-s respectively. The test also requires that the null hypothesis $\left(\mathrm{H}_{0}\right)$ be rejected for accumulating evidence of co-integration of at least one of the cross-sectional units. The $\mathrm{P}_{\mathrm{a}}$ and $\mathrm{P}_{\mathrm{t}}$ test statistics pool information over all the cross-sectional units to test $\mathrm{H}_{0}: \mathrm{a}_{\mathrm{i}}=0$ for all $i,(i=1, \ldots N)$ and $H 1:: a_{i}<0$ for all $I$, $(\mathrm{i}=1, \ldots \mathrm{N})$. Rejection of $\mathrm{H}_{0}$ is thus substantial to validate existence of cointegration given the entire panel.

After identifying the co-integration linkages between dependent and independent variables, this paper adopts the two-step system generalized method of moments (SGMM) method for a dynamic panel of the whole sample as well as for 
cluster data to determine the levels of effects of tax revenue and government expenditure on economic growth in both developed and developing countries. According to the numerous previous studies, this technique can help achieve more consistent endogenous growth model than fixed effects method (Arrellano \& Bond, 1991; Baltagi, 2005; d'Agostino et al., 2012; Sasaki, 2015).

Furthermore, endogenous variables always appear in growth models, which causes bias to OLS regression, and using exogenous instruments could help regressors fix this issue (Barro 1990; Acemoglu et al., 2001). Siddiqui and Ahmed (2013) indicated that generalized method of moments (GMM) is an instrumental technique, which handles the endogenous phenomenon as well as the matter of inefficiency in the presence of heteroskedasticity. Owing to the bias of the lagged dependent variable in the right-handside, the first-different GMM helps regressors elimilate the bias of fixed effects and unobserved error term effects (Arellanon \& Bond, 1991; Roodman, 2009). In addition, Windmeijer (2005) revealed that the two-step GMM procedure obtains consistent and efficient parameters of estimation. This study, therefore, applies two-step SGMM to the dynamic panel data of 38 developed and 44 developing countries in a 16 -year period.

In accordance with Barro (1990) and Barro and Sala-i-Martin (1992), the empirical model for estimating degrees of effects of tax revenue and government expenditure on economic growth are as below:

$$
\begin{gathered}
\operatorname{lrgdp}_{i, t}=\alpha_{0}+\alpha_{1} \operatorname{lrgdp}_{i, t-1}+ \\
\alpha_{2} \operatorname{taxrev}_{i, t}+\alpha_{3} \operatorname{infl}_{i, t}+\alpha_{4} \text { tradeop }_{i, t}+ \\
\alpha_{5} \operatorname{tinv}_{i, t}+\alpha_{6} \operatorname{topop}_{i, t}+\alpha_{7} \text { hdi }_{i, t}+\varepsilon_{i, t}+ \\
\vartheta_{i, t}
\end{gathered}
$$

$$
\begin{gathered}
\operatorname{lrgdp}_{i, t}=\alpha_{0}+\alpha_{1} \operatorname{lrgdp}_{i, t-1}+ \\
\alpha_{2} \operatorname{gexp}_{i, t}+\alpha_{3} \operatorname{infl}_{i, t}+\alpha_{4} \operatorname{tradeop}_{i, t}+ \\
\alpha_{5} \operatorname{tinv}_{i, t}+\alpha_{6} \operatorname{topop}_{i, t}+\alpha_{7} \operatorname{hdi}_{i, t}+\varepsilon_{i, t}+ \\
\vartheta_{i, t}, \quad \text { (4b) }
\end{gathered}
$$

where, infli,t is Inflation of country $\mathrm{i}$ $(\mathrm{i}=1, \ldots \mathrm{N})$ at time $\mathrm{t}(\mathrm{t}=1, \ldots \mathrm{T})$, tradeop $_{i, t}$ stands for trade openness, $\operatorname{tinv}_{i, t}$ represents total investment, topop $i, t$ is total population, and $h d i_{i, t}$ is human development index, surveyed and measured by United Nations Development Program (UNDP).

\section{Empirical data and findings}

We extract the annual data for the whole sample, which includes 38 developed and 44 developing countries over a 16-year period (2000-2015) (see Appendix B-List of studied countries), and the strong balanced panel data is used for analysis (see Table 1Description of variables). 


\section{Table 1}

Description of variables (for the whole sample of 82 developed and developing countries)

\begin{tabular}{|c|c|c|c|c|c|c|}
\hline Meaning and source & Variable & Obs. & Mean & Std. dev. & Min & Max \\
\hline $\begin{array}{l}\text { Real gross domestic per } \\
\text { capita (US dollars) - } \\
\text { world bank website } \\
\text { (WB) (updated on } \\
\text { August } 10,2016)\end{array}$ & $r g d p$ & 1312 & $16,948.350$ & $19,550.880$ & 194.169 & $91,593.630$ \\
\hline $\begin{array}{l}\text { Total tax revenue ( } \% \text { of } \\
\text { GDP) - International } \\
\text { Monetary Fund (IMF) } \\
\text { (updated in April 2016) }\end{array}$ & taxrev & 1312 & 30.561 & 11.522 & 8.489 & 57.435 \\
\hline $\begin{array}{l}\text { Total government } \\
\text { expenditure }(\% \text { of } \\
\text { GDP })-(\text { IMF }) \text { (updated } \\
\text { in April 2016) }\end{array}$ & gexp & 1312 & 32.731 & 11.519 & 10.529 & 65.572 \\
\hline $\begin{array}{l}\text { Inflation(Consumer } \\
\text { annual Price index) - } \\
\text { (WB) }\end{array}$ & infl & 1312 & 5.199 & 7.550 & -8.238 & 168.620 \\
\hline $\begin{array}{l}\text { Trade }(\% \text { of } \text { GDP) - } \\
\text { (WB) }\end{array}$ & tradeop & 1312 & 82.488 & 57.468 & 4.692 & 439.657 \\
\hline $\begin{array}{l}\text { Total domestic } \\
\text { investment (\% of GDP) } \\
-\quad(\text { IMF) (updated in } \\
\text { April 2016) }\end{array}$ & $\operatorname{tinv}$ & 1312 & 23.586 & 5.981 & 8.675 & 58.151 \\
\hline $\begin{array}{l}\text { Total population } \\
(\text { People })-(\text { WB })\end{array}$ & topop & 1312 & $5 \mathrm{E}+07$ & $1.4 \mathrm{E}+08$ & 81,131 & $1.3 \mathrm{E}+09$ \\
\hline $\begin{array}{l}\text { Human development } \\
\text { index (index) - United } \\
\text { Nations development } \\
\text { program (UNDP) }\end{array}$ & $h d i$ & 1312 & 0.727 & 0.150 & 0.283 & 0.949 \\
\hline
\end{tabular}

Table 1 shows the big gap between developed and developing countries in real GDP per capita, tax revenue, and expenditure. 
Table 2

Correlation matrix (for the whole sample of 82 developed and developing countries)

\begin{tabular}{|c|c|c|c|c|c|c|c|c|}
\hline & lrgdp & taxrev & gexp & infl & tradeop & tinv & topop & hdi \\
\hline $\operatorname{lrgdp}$ & 1 & & & & & & & \\
\hline \multirow[t]{2}{*}{ taxrev } & $0.745^{* * *}$ & 1 & & & & & & \\
\hline & 0.000 & & & & & & & \\
\hline \multirow[t]{2}{*}{ gexp } & $0.695^{* * *}$ & $0.933^{* * *}$ & 1 & & & & & \\
\hline & 0.000 & 0.000 & & & & & & \\
\hline \multirow[t]{2}{*}{ infl } & $-0.279^{* * *}$ & $-0.176^{* * *}$ & $-0.189^{* * *}$ & 1 & & & & \\
\hline & 0.000 & 0.000 & 0.000 & & & & & \\
\hline \multirow[t]{2}{*}{ tradeop } & $0.137^{* * *}$ & $0.104^{* * *}$ & $0.059^{*}$ & -0.017 & 1 & & & \\
\hline & 0.000 & 0.000 & 0.034 & 0.536 & & & & \\
\hline \multirow[t]{2}{*}{ tinv } & -0.036 & -0.010 & $-0.068^{* *}$ & $0.174^{* * *}$ & $0.164^{* * *}$ & 1 & & \\
\hline & 0.195 & 0.705 & 0.015 & 0.000 & 0.000 & & & \\
\hline \multirow[t]{2}{*}{ topop } & $-0.155^{* * *}$ & $-0.193^{* * *}$ & $-0.136^{* * *}$ & $0.069^{* *}$ & $-0.202^{* * *}$ & $0.155^{* * *}$ & 1 & \\
\hline & 0.000 & 0.000 & 0.000 & 0.013 & 0.000 & 0.000 & & \\
\hline \multirow[t]{2}{*}{ hdi } & $0.862^{* * *}$ & $0.697^{* * *}$ & $0.679^{* * *}$ & $-0.189^{* * *}$ & $0.142^{* * *}$ & $0.050^{*}$ & $-0.133^{* * *}$ & 1 \\
\hline & 0.000 & 0.000 & 0.000 & 0.000 & 0.000 & 0.068 & 0.000 & \\
\hline
\end{tabular}

Note: ${ }^{*} \mathrm{p}<0.1,{ }^{* *} \mathrm{p}<0.05,{ }^{* * *} \mathrm{p}<0.01$

Through Table 2, it can be observed that tax revenue and expenditure are significantly and strongly correlated with economic growth and that tax revenue and expenditure are closely correlated with each other. 


\section{Table 3a}

Results of unit root test for a panel with normal data for the whole sample in 20002015

\begin{tabular}{lccc|ccc} 
Normal & \multicolumn{3}{c}{ HT test } & \multicolumn{3}{c}{ IPS test } \\
\hline & rho Statistic & $\mathrm{z}$ & $\mathrm{p}$-value & Statistic & p-value & $\begin{array}{c}\text { AIC chosen lags } \\
\text { average }\end{array}$ \\
\hline rgdp & 0.904 & 4.000 & 1.000 & 8.270 & 1.000 & 0.45 \\
lrgdp & 0.935 & 5.544 & 1.000 & 3.136 & 0.999 & 0.45 \\
taxrev & $0.4871^{* * *}$ & -16.778 & 0.000 & $-3.679^{* * *}$ & 0.000 & 0.50 \\
gexp & $0.618^{* * *}$ & -10.266 & 0.000 & $-4.008^{* * *}$ & 0.000 & 0.48 \\
hdi & 0.908 & 4.191 & 1.000 & -0.458 & 0.324 & 0.51 \\
infl & $0.331^{* * *}$ & -24.551 & 0.000 & $-12.643^{* * *}$ & 0.000 & 0.34 \\
tradeop & 0.794 & -1.478 & 0.0697 & $-1.981^{* *}$ & 0.023 & 0.65 \\
tinv & $0.715^{* * *}$ & -5.414 & 0.000 & $-1.789^{* *}$ & 0.0368 & 0.41 \\
topop & 0.989 & 8.267 & 1.000 & 7.724 & 1.000 & 1.50 \\
ltopop & $0.342^{* * *}$ & -20.241 & 0.000 & $-3.557^{* * *}$ & 0.000 & 1.540 \\
\hline
\end{tabular}

Note: ${ }^{*} \mathrm{p}<0.1,{ }^{* *} \mathrm{p}<0.05,{ }^{* * *} \mathrm{p}<0.01$

The table shows three variables that do not stay significant, including "real income per capita," "human development indicator," and "total population." This finding is underpinned by Bujang et al. (2013), which demands identification of co-integration linkages between non-stationary variables and others.

This study continues by running the unit root test for first different values of variables, noting that all variables stay significant at first differences concerning both HT and IPS test. The variable "total population" is significant after taking the first difference of logarithm using IPS test. 


\section{Table 3b}

Results of unit root test for a panel with data of first different values for the whole sample in 2000-2015

\begin{tabular}{|c|c|c|c|c|c|c|}
\hline First difference & & HT test & & & IPS tes & \\
\hline & $\begin{array}{c}\text { rho } \\
\text { Statistic }\end{array}$ & $\mathrm{z}$ & p-value & Statistic & p-value & $\begin{array}{c}\text { AIC } \\
\text { chosen lags } \\
\text { average }\end{array}$ \\
\hline$\Delta . r g d p$ & $0.263^{* * *}$ & -25.835 & 0.000 & $-12.688^{* * *}$ & 0.000 & 0.43 \\
\hline$\Delta . \operatorname{lrg} d p$ & $0.295^{* * *}$ & -24.326 & 0.000 & $-12.517^{* * *}$ & 0.000 & 0.39 \\
\hline$\Delta$. taxrev & $-0.251^{* * *}$ & -50.038 & 0.000 & $-22.404^{* * *}$ & 0.000 & 0.37 \\
\hline$\Delta . g \exp$ & $-0.093^{* * *}$ & -42.598 & 0.000 & $-22.405^{* * *}$ & 0.000 & 0.32 \\
\hline$\Delta . h d i$ & $0.194^{* * *}$ & -29.074 & 0.000 & $-14.013^{* * *}$ & 0.000 & 0.23 \\
\hline$\Delta$. infl & $-0.071^{* * *}$ & -41.564 & 0.000 & $-31.341^{* * *}$ & 0.000 & 0.76 \\
\hline A.tradeop & $-0.114^{* * *}$ & -43.586 & 0.000 & $-20.248^{* * *}$ & 0.000 & 0.38 \\
\hline$\Delta . t i n v$ & $-0.110^{* * *}$ & -43.375 & 0.000 & $-21.673^{* * *}$ & 0.000 & 0.41 \\
\hline ४.topop & $0.591^{* * *}$ & -10.413 & 0.000 & $2.045^{* * *}$ & 0.980 & 1.37 \\
\hline А.ltopop & $0.366^{* * *}$ & -20.993 & 0.000 & $-6.039^{* * *}$ & 0.000 & 1.28 \\
\hline
\end{tabular}

Note: ${ }^{*} \mathrm{p}<0.1,{ }^{* *} \mathrm{p}<0.05,{ }^{* * *} \mathrm{p}<0.01$

Tables $3 a$ and $3 b$ show the evidence of stationarity for all variables; it means that a unit root is absent from the error term in the panel dataset.

\section{Table 4}

\section{Pairwise Granger test results}

\begin{tabular}{lllll}
\hline $\begin{array}{l}\mathrm{H}_{0}: \text { Government expenditure does not Granger cause tax } \\
\text { revenue (dependent variable: taxrev) }\end{array}$ & Obs. & z-Stat & Prob. \\
\hline gexp $\rightarrow$ taxrev & 1312 & $36.71^{* * *}$ & 0.000 \\
\hline $\begin{array}{l}\mathrm{H}_{0}: \text { Tax revenue does not Granger cause government } \\
\text { expenditure (dependent variable: gexp) }\end{array}$ & & & \\
\hline taxrev $\rightarrow$ gexp & 1312 & $36.12^{* * *}$ & 0.000 \\
\hline Note: ${ }^{*} \mathrm{p}<0.1,{ }^{* *} \mathrm{p}<0.05,{ }^{* * *} \mathrm{p}<0.01$ & & &
\end{tabular}




\section{Table 5}

Westerlund long-run cointegration test: Dependent variable: $\operatorname{lrg} d p$ (Average AIC selected lag length: 1)

\begin{tabular}{|c|c|c|c|c|c|c|c|c|c|}
\hline \multicolumn{4}{|c|}{ taxrev - lrgdp } & \multicolumn{3}{|c|}{ gexp - lrgdp } & \multicolumn{3}{|c|}{ infl - lrgdp } \\
\hline Statistic & Value & Z-value & P-value & Value & Z-value & P-value & Value & Z-value & P-value \\
\hline Gt & $-3.357^{* * *}$ & -11.281 & 0.000 & $-2.610^{* * *}$ & -2.863 & 0.002 & $-3.425^{* * *}$ & -12.050 & 0.000 \\
\hline $\mathrm{Ga}$ & $-20.018^{* * *}$ & -11.055 & 0.000 & $-19.169^{* * *}$ & -9.898 & 0.000 & $-20.294^{* * *}$ & -11.430 & 0.000 \\
\hline $\mathrm{Pt}$ & $-22.008^{* * *}$ & -3.349 & 0.000 & -16.047 & 3.594 & 1.000 & -17.625 & 1.755 & 0.960 \\
\hline $\mathrm{Pa}$ & $-14.012^{* * *}$ & -7.668 & 0.000 & $-9.865^{*}$ & -1.381 & 0.084 & $-12.605^{* * *}$ & -5.536 & 0.000 \\
\hline \multicolumn{2}{|c|}{ AIC lead length: } & \multicolumn{2}{|l|}{0.55} & \multicolumn{3}{|l|}{0.63} & \multicolumn{3}{|l|}{0.63} \\
\hline & \multicolumn{2}{|c|}{ tradeop - lrgdp } & & \multicolumn{2}{|c|}{ tinv - lrgdp } & & \multicolumn{3}{|c|}{ hdi - lrgdp } \\
\hline Statistic & Value & Z-value & P-value & Value & Z-value & P-value & Value & Z-value & P-value \\
\hline Gt & $-2.801^{* * *}$ & -5.020 & 0.000 & $-3.610^{* * *}$ & -14.141 & 0.000 & $-3.968^{* * *}$ & -18.175 & 0.000 \\
\hline $\mathrm{Ga}$ & $-18.042^{* * *}$ & -8.364 & 0.000 & $-19.987^{* * *}$ & -11.012 & 0.000 & $-16.905^{* * *}$ & -6.817 & 0.000 \\
\hline $\mathrm{Pt}$ & -19.057 & 0.087 & 0.535 & $-21.637^{* * *}$ & -2.917 & 0.002 & $-24.096^{* * *}$ & -5.782 & 0.000 \\
\hline $\mathrm{Pa}$ & $-12.740^{* * *}$ & -5.739 & 0.000 & $-16.441^{* * *}$ & -11.351 & 0.000 & $-14.605^{* * *}$ & -8.567 & 0.000 \\
\hline \multicolumn{2}{|c|}{ AIC lead length: } & \multicolumn{2}{|l|}{0.71} & \multicolumn{3}{|l|}{0.74} & \multicolumn{3}{|l|}{0.63} \\
\hline \multicolumn{4}{|c|}{ topop - 1rgdp } & & & & & & \\
\hline Statistic & Value & Z-value & P-value & & & & & & \\
\hline Gt & $-4.912^{* * *}$ & -11.281 & 0.000 & & & & & & \\
\hline $\mathrm{Ga}$ & $-13.336^{* * *}$ & -11.055 & 0.000 & & & & & & \\
\hline $\mathrm{Pt}$ & $-24.764^{* * *}$ & -3.349 & 0.000 & & & & & & \\
\hline $\mathrm{Pa}$ & $-10.743^{* * *}$ & -7.668 & 0.000 & & & & & & \\
\hline AIC lead & ength: & 0.71 & & & & & & & \\
\hline
\end{tabular}

Note: ${ }^{*} \mathrm{p}<0.1,{ }^{* *} \mathrm{p}<0.05,{ }^{* * *} \mathrm{p}<0.01$

Table 4 indicates that there exists a bidirectional and causal relationship between tax revenue and government, which supports the fiscal synchronization hypothesis that is justified by a few previous studies such as Musgrave (1966), Meltzer and Richard (1981), Bohn (1991), and Chang and Chiang (2009). This result also suggests that policy makers in both developed and developing countries should focus on the important role of total tax revenue and expenditure for larger government budget as well as increasing economic outcomes to develop appropriate fiscal synchronization in these economies.

Before performing regression analysis of 
the level effects of tax revenue, expenditure, and economic growth, this research employs co-integration test to avoid bias from nonstationary variables and answer the second research question: "Do co-integration relationships exist among tax revenue, government spending, and long-run econmic growth?"

Co-integration test results:

$H_{0}$ : In each pair of variables there exists no long-term co-integration linkageThe cointegration test results indicate that the linkages between tax revenue or expenditure and economic growth are co-integrated. Interestingly, this finding supports not only the line trend graphs discussed earlier (see Appendix A) but also the fiscal synchronization hypothesis confirmed by Chang and Chiang (2009) for the case of 15 OECD countries over the 1992-2006 period.

Furthermore, to overcome the limitation of previous studies that run causality or cointegration test for investigating the correlations among tax revenue, expenditure, and long-run economic growth, this research also seeks to determine the degrees of effects of these two variables on economic growth.

In light of the bias caused by the dynamic characteristic of strong balanced panel data of 82 countries in a 16-year period, this research applies the two-step system generalized method of moments (SGMM) to estimate the level effects of tax revenue and expenditure on economic growth (Baltagi, 2005.) Roodman (2009) noted that SGMM estimation typically includes more instruments, which therefore increases the efficiency of the regression. To apply the SGMM estimation we conduct the Hansen test of over-identifying restrictions to check the null hypothesis that the instrumental variables are exogenous. If the null hypothesis can be rejected, then the SGMM estimation can fix the problem of endogeneity, and the regression will provide results with small bias. In the case of "large $\mathrm{N}$ and small T," the Hansen test is appropriate to verify the endogenous phenomenon (Hansen, 1982; Baltagi, 2005). Using dynamic panel data always encounters autocorrelation problems. For this reason we employ Arellano-Bond test to identify the autocorrelation of different error terms; it involves $\mathrm{E}\left(\Delta U_{i t}, \Delta U_{i t-2}=0\right)$ (Arellano \& Bond, 1991). We also apply two types of unit root test to identify stationary variables before running SGMM for reducing bias from time series data in longrun period. Most variables stay significant at first lag or first differences given HT and IPS unit root tests (see Tables $3 a$ and $3 b$ ).

Results two-step system generalized method of moment estimation: 


\section{Table 6a}

Level effects of tax revenue and government expenditure (for the whole sample of 82 developed and developing countries)

(4a) Dependent variable: $\operatorname{lrgdp}$

(4b) Dependent variable: 1 rgdp

\begin{tabular}{|c|c|c|c|c|c|c|c|}
\hline & Coef. & $\mathrm{z}$ & $\mathrm{P}>\mathrm{z}$ & & Coef. & $\mathrm{z}$ & $\mathrm{P}>\mathrm{z}$ \\
\hline lrgdp (L1). & $0.993^{* * *}$ & 792.560 & 0.000 & lrgdp (L1). & $0.994^{* * *}$ & $1,059.920$ & 0.000 \\
\hline taxrev & $0.001^{* * *}$ & 8.830 & 0.000 & gexp & $-0.0002^{* *}$ & -2.46 & 0.014 \\
\hline infl & $-0.001^{* * *}$ & -26.660 & 0.000 & infl & $-0.001^{* * *}$ & -41.95 & 0.000 \\
\hline tradeop & $0.0003^{* * *}$ & 8.710 & 0.000 & tradeop & $0.0002^{* * *}$ & 10.130 & 0.000 \\
\hline tinv & $0.004^{* * *}$ & 31.240 & 0.000 & tinv & $0.003^{* * *}$ & 41.630 & 0.000 \\
\hline topop & $0.000^{* * *}$ & 4.620 & 0.000 & topop & $0.000^{* * *}$ & 3.670 & 0.000 \\
\hline hdi & $-0.085^{* * *}$ & -5.420 & 0.000 & hdi & $-0.024^{* * *}$ & -2.99 & 0.003 \\
\hline \multicolumn{3}{|c|}{ Number of obs. } & 1066 & \multicolumn{3}{|c|}{ Number of obs. } & 1066 \\
\hline \multicolumn{3}{|c|}{ Number of groups } & 82 & \multicolumn{3}{|c|}{ Number of groups } & 82 \\
\hline \multicolumn{3}{|c|}{ Number of instruments } & 77 & \multicolumn{3}{|c|}{ Number of instruments } & 80 \\
\hline \multicolumn{3}{|l|}{$\mathrm{AR}(2)$} & 0.155 & \multicolumn{3}{|l|}{$\operatorname{AR}(2)$} & 0.222 \\
\hline \multicolumn{3}{|l|}{ Hansen test } & 0.194 & \multicolumn{3}{|l|}{ Hansen test } & 0.274 \\
\hline \multicolumn{3}{|l|}{ Wald chi2(7) } & 2. $E+07$ & \multicolumn{3}{|c|}{ Wald chi2(7) } & $5.28 \mathrm{E}+07$ \\
\hline \multicolumn{3}{|l|}{ Prob $>$ chi 2} & 0.000 & \multicolumn{3}{|l|}{ Prob $>$ chi 2} & 0.000 \\
\hline
\end{tabular}

Note: ${ }^{*} \mathrm{p}<0.1,{ }^{* *} \mathrm{p}<0.05,{ }^{* * *} \mathrm{p}<0.01$

\section{Table 6b}

Level effects of tax revenue and government expenditure (for 44 developing countries)

(4a) Dependent variable: lrgdp

(4b) Dependent variable: $\operatorname{lrgdp}$

\begin{tabular}{lccc|lccc}
\hline & Coef. & $\mathrm{Z}$ & $\mathrm{P}>\mathrm{Z}$ & & $\mathrm{Coef}$ & $\mathrm{Z}$ & $\mathrm{P}>\mathrm{Z}$ \\
\hline $\operatorname{lrgdp}(\mathrm{L} 1)$. & $0.93^{* * *}$ & 873.64 & 0.000 & $\operatorname{lrgdp}(\mathrm{L} 1)$. & $1.023^{* * *}$ & 482.270 & 0.000 \\
& & & & & & \\
taxrev & $0.85^{* * *}$ & 2.75 & 0.006 & gexp & $15.563^{* * *}$ & 17.270 & 0.000 \\
infl & $-0.76^{* *}$ & -2.06 & 0.040 & infl & -0.239 & -0.310 & 0.756 \\
tradeop & $-2.92^{* * *}$ & -34.13 & 0.000 & tradeop & $-5.214^{* * *}$ & -12.020 & 0.000
\end{tabular}


(4a) Dependent variable: 1 rgdp

(4b) Dependent variable: 1rgdp

\begin{tabular}{|c|c|c|c|c|c|c|c|}
\hline & Coef. & z & $\mathrm{P}>\mathrm{Z}$ & & Coef. & z & $\mathrm{P}>\mathrm{Z}$ \\
\hline tinv & $5.88^{* * *}$ & 23.30 & 0.000 & $\operatorname{tinv}$ & $1.258^{* * *}$ & 5.870 & 0.000 \\
\hline topop & 0.000 & 0.05 & 0.962 & topop & $0.000^{* * *}$ & -4.460 & 0.000 \\
\hline hdi & $-24.30^{* * *}$ & -64.49 & 0.000 & hdi & $-16.145^{* * *}$ & -19.660 & 0.000 \\
\hline \multicolumn{3}{|c|}{ Number of obs. } & 616 & \multicolumn{3}{|c|}{ Number of obs. } & 573 \\
\hline \multicolumn{3}{|c|}{ Number of groups } & 44 & \multicolumn{3}{|c|}{ Number of groups } & 44 \\
\hline \multicolumn{3}{|c|}{ Number of instruments } & 38 & \multicolumn{3}{|c|}{ Number of instruments } & 36 \\
\hline \multicolumn{3}{|l|}{$\operatorname{AR}(2)$} & 0.1975 & \multicolumn{3}{|l|}{$\operatorname{AR}(2)$} & 0.2035 \\
\hline \multicolumn{3}{|c|}{ Hansen test } & 0.3753 & \multicolumn{3}{|c|}{ Hansen test } & 0.231 \\
\hline \multicolumn{3}{|c|}{ Wald chi2(7) } & $4.51 \mathrm{E}+09$ & \multicolumn{3}{|c|}{ Wald chi2(7) } & $3.01 \mathrm{E}+08$ \\
\hline \multicolumn{3}{|c|}{ Prob $>$ chi2 } & 0.000 & \multicolumn{3}{|c|}{ Prob $>$ chi 2} & 0.000 \\
\hline
\end{tabular}

Note: ${ }^{*} \mathrm{p}<0.1,{ }^{* *} \mathrm{p}<0.05,{ }^{* * *} \mathrm{p}<0.01$

\section{Table 6c}

Level effects of tax revenue and government expenditure (for developed countries only)

(4a) Dependent variable: lrgdp

(4b) Dependent variable: $\operatorname{lrgdp}$

\begin{tabular}{|c|c|c|c|c|c|c|c|}
\hline & Coef. & $\mathrm{z}$ & $\mathrm{P}>\mathrm{Z}$ & & Coef. & $\mathrm{z}$ & $\mathrm{P}>\mathrm{z}$ \\
\hline $\begin{array}{l}\text { lrgdp } \\
\text { (L1). }\end{array}$ & $0.969^{* * *}$ & 162.570 & 0.000 & $\begin{array}{l}\text { lrgdp } \\
\text { (L1). }\end{array}$ & $0.562^{* * *}$ & 40.440 & 0.000 \\
\hline taxrev & $0.001^{* * *}$ & 3.120 & 0.002 & gexp & $-0.004^{* * *}$ & -12.960 & 0.000 \\
\hline infl & $-0.005^{* * *}$ & 4.560 & 0.000 & infl & $-0.001^{* * *}$ & -6.490 & 0.000 \\
\hline tradeop & $0.000^{* * *}$ & 2.950 & 0.003 & tradeop & $0.001^{* * *}$ & 19.410 & 0.000 \\
\hline tinv & $0.004^{* * *}$ & 10.030 & 0.000 & $\operatorname{tinv}$ & $0.004^{* * *}$ & 32.200 & 0.000 \\
\hline topop & $0.000^{* *}$ & 2.320 & 0.021 & topop & $0.000^{*}$ & -1.870 & 0.061 \\
\hline hdi & $0.248^{* * *}$ & 3.160 & 0.002 & hdi & $2.030^{* * *}$ & 20.450 & 0.000 \\
\hline \multicolumn{3}{|c|}{ Number of obs. } & 570 & \multicolumn{3}{|c|}{ Number of obs. } & 503 \\
\hline \multicolumn{3}{|c|}{ Number of groups } & 38 & \multicolumn{3}{|c|}{ Number of groups } & 38 \\
\hline \multicolumn{3}{|c|}{ Number of instruments } & 30 & \multicolumn{3}{|c|}{ Number of instruments } & 36 \\
\hline \multicolumn{3}{|l|}{$\operatorname{AR}(2)$} & 0.81 & \multicolumn{3}{|l|}{$\operatorname{AR}(2)$} & 0.51 \\
\hline
\end{tabular}


(4a) Dependent variable: $\operatorname{lrgdp}$

(4b) Dependent variable: $\operatorname{lrgdp}$

\begin{tabular}{|c|c|c|c|c|c|}
\hline Coef. & $\mathrm{z}$ & $\mathrm{P}>\mathrm{Z}$ & Coef. & $\mathrm{z}$ & $\mathrm{P}>\mathrm{Z}$ \\
\hline Hansen test & & 0.32 & Hansen test & & 0.13 \\
\hline Wald chi2(7) & & $2.60 \mathrm{E}+05$ & Wald chi2(7) & & $5.66 \mathrm{E}+04$ \\
\hline Prob $>$ chi 2 & & 0.000 & Prob $>$ chi 2 & & 0.000 \\
\hline
\end{tabular}

Note: ${ }^{*} \mathrm{p}<0.1,{ }^{* *} \mathrm{p}<0.05,{ }^{* * *} \mathrm{p}<0.01$

Tables $6 \mathrm{a}, 6 \mathrm{~b}$, and $6 \mathrm{c}$ show the impacts of total tax revenue (taxrev) and total investment (tinv), and most of those of total population (topop) on economic growth for the three models are positive and significant at $1 \%$ level. These findings advocate the studies of Alizadeh et al. (2015), who, by using the error correction model, indicated that tax revenue is crucial in increasing GDP per capita. Applying neo-classical model for 98 countries in a 26-year period, Barro (1991) argued that tax revenue promotes investment and indirectly boosts economic growth. However, inflation, as also suggested, reduces income per capita. Additionally, government expenditure is found to exert a negative effect on economic growth considering both the whole sample and the case of developing countries. These results enrich the literature of Samuelson (1954), Barro (1991), and Edwards (1998).

It is most noteworthy that human development indicator $(h d i)$ and government expenditure (gexp) for the group of developed countries are different from those for the whole sample and the group of developing countries alone. Increases in these variables lead to improved GDP per capita.

Specifically, in developing countries, human development and trade openness

(tradeop) are harmful to the wellbeing of these economies. Jenkins (2004) posited that in Vietnam the import value is attributable to a decline in the economic growth rate, while the export value contributes to increased economic growth. On the other hand, while Dumith et al. (2011) found that high human development index gives rise to the physical inactivity in both developed and developing countries, Atkinson (2016) confirmed this finding for developing countries only. Future reasearch shall be conducted for better understanding of the issue with human development index as well as trade openess.

\section{Conclusion and limitations}

This study applies the Granger pairwise causality test and confirms the synchronization hypothesis that a bidirectional causal relationship exists between tax revenue and expenditure. Second, by employing the Persyn and Westerlund's (2008) test, co-integration liankages are found between the variables tax revenue or expenditure and economic growth in both developed and developing countries. The two-step system generalized method of moments estimation reveals that tax revenue always positively affects economic growth. In constrast, government 
expenditure impacts differently on economic growth depending on different kinds of economic groups. Furthermore, there is a big gap between developed and developing countries. For the group of 38 developed countries, substantial evidence is accumulated of more government tax collection yet less spending. Given the case of 44 developing countries, nevertheless, the results verify that governments spend more but impose less tax, which eventually results in more rapid growth. These findings are in support of both "fiscal synchronization" and "spend-tax" hypotheses. On that basis, suitable and effective fiscal policies can be subsequently formulated to promote healthy development of these economies during the coming years.

The first limitation of this research is that no analysis has been performed of the structure of tax revenue as well as components of government expenditure to further capture the role of these variables in an economy. Second, this study could not find out a plausible reason for profound effects of trade openness and human development index on economic growth for both the groups of developed and developing countries, which leaves another gap for future discussions to be held

\section{References}

Acemoglu, D., Johnson, S., \& Robinson, J. A. (2005). Institutions as a fundamental cause of longterm growth. In P. Aghion \& S. N. Durlauf (Eds.), Handbook of economic growth (pp. 385-472). Elsevier, Cambridge.

Acemoglu, D. (2006). A simple model of inefficient institutions. Scandinavian Journal of Economics, $108(4), 515-546$.

Adkisson, R. V., \& Mohammed, M. (2014). Tax structure and state economic growth during the Great Recession. The Social Science Journal, 51(2014), 79-89.

Amir, H., Asafu-Adjaye, J., \& Ducpham, T. (2013). The impact of the Indonesian income tax reform: A CGE analysis. Economic Modelling, 31(2013), 492-501.

Arellano, M., \& Bond, S. (1991). Some tests of specification for panel data: Monte Carlo evidence and an application to employment equations. Review of Economic Studies, 58(2), 277-297.

Atkinson, K., Lowe, S., \& Moore, S. (2016). Human development, occupational structure and physical inactivity among 47 low and middle income countries. Preventive Medicine Reports, 3(2016), 40-45.

Attila, G. (2009). Corruption, taxation and economic growth: Theory and evidence. Recherches Économiques de Louvain, 75(2), 229-268.

Baltagi, B. H. (2005). Econometric analysis of panel data. JohnWiley \& Sons Ltd., West Sussex PO19 8SQ, England.

Barro, R. J. (1990). Government spending in a simple model of endogenous growth. The Journal of Political Economy, 98(5), S130-S125.

Barro, R. J. (1991). Economic growth in a cross section of countries. Quarterly Journal of Economics, 
106(2), 407-443.

Barro, R. J., \& Sala-i-Martin, X. (1999). Public finance in models of economic growth. The Review of Economic Studies, 59(4), 645-661.

Blackley, P. (1986). Causality between revenues and expenditures and the size of the federal budget. Public Finance Quarterly, 14(1986), 139-156.

Bohn, H. (1991). Budget balance through revenue or spending adjustment? Some historical evidence for the United States. Journal of Monetary Economics, 27(1991), 333-359.

Buchanan, J. M. (1999). Public finance in democratic process: Fiscal institutions and individual choice. Liberty fund, North Carolina.

Bujang, I., Abd, T., \& Ahmad, I. (2013). Tax structure and economic indicators in developing and high-income OECD countries: Panel cointegration analysis. Procedia Economics and Finance, 7(2013), 164-173.

Chang, T., \& Chiang, G. (2009). Revisiting the government revenue-expenditure nexus: Evidence from 15 OECD countries based on the panel data analysis. Finance a úve - Czech Journal of Economics and Finance, 59(2).

Cooray, A. (2009). Government expenditure, governance and economic growth. Comparative Economic Studies, 51(2009), 401-418.

d'Agostino, G., Dunne, J. P., \& Pieroni, L. (2012). Corruption, military spending and growth. Defence and Peace Economics, 23(6), 591-604.

Darrat, A. F. (1998). Tax and spend, or spend and tax? An inquriry into the Turkish budgetary process. Southern Economic Journal, 64(1988), 940-956.

Dzhumashev, R. (2014). Corruption and growth: The role of governance, public spending, and economic development. Economic Modelling, 37, 2013-2015.

Dumith, S. C., Hallal, P. C., Reis, R. S., \& Kohl, H. W. (2011). Worldwide prevalence of physical inactivity and its association with human development index in 76 countries. Preventive Medicine, 53(1-2), 24-28.

Easterly, W., \& Rebelo, S. (1993). Fiscal policy and economic growth. Journal of Monetary Economics, 32, 417-458.

Edwards, S. (1998). Openess, productivity and growth: What do we really know? Economic Journal, 108(447), 383-398.

Friedman, M. (1978). The limitations of tax limitations. Policy Review, 7-14.

Granger, C. W. J. (1969). Investigating causal relations by econometric models and cross-spectral methods. Econometrica, 37(3), 424-438.

Hansan, S. A., Subhani, M. I., \& Osman, A. (2012). An investigation of Granger causality between tax revenue and government expenditure. Working paper series MPRA paper No. 35686, Posted 2. January UTC.

Hansen, L. P. (1982). Large sample properties of generalised method of moments estimators. Econometrica, 50(4), 1029-1054.

Hitiris, T., \& Posnett, J. (1992). The determinants and effects of health expenditure in developed 
countries. Journal of Health Economics, 11(2), 173-181.

Holley, H. U. (2011). Public finance in theory and practice (2nd Ed.). Routledge, New York.

Kaul, I., \& ConceiÇÃo, P. (2006). The new public finance: Responding to global challenges. United Nations development programme, New York.

Kneller, R., Bleaney, M. F., \& Gemmell, N. (1999). Fiscal policy and growth: Evidence from OECD countries. Journal of Public Economics, 74(2), 171-190.

Lee, Y., \& Gordon, R. H. (2005). Tax structure and economic growth. Journal of Public Economics, 89(2005), 1027-1043.

Mahdavi, S., \& Westerlund, J. (2008). The tax spending nexus: Evidences from a panel of US statelocal governments. Working paper series WP\#0045\#ECO-090-2008, The University of Texas at San Antonio, May.

McGee, R. W. (2013). The philosophy of taxation and public finance. Kluwer academic publishers, Boston/Dordrecht/Lodon.

Meltzer, A. H., \& Richard, S. F. (1981). A ratinal theory of the size of government. Journal of Political Economy, 89(1981), 914-924.

Musgrave, R. (1966). Principles of budget determination. In H. Cameron \& W. Henderson (Eds.), Public finance: Selected readings. Random House, New York.

Nguyen, P. L. (2015). Impact of institutional quality on tax revenue in developing countries. Asian journal of empirical research, 5(10), 181-195.

Ojede, A., \& Yamarik, S. (2012). Tax policy and state economic growth: The long-run and short-run of it. Economics Letters, 116(2), 161-165.

Persyn, D., \& Westerlund, J. (2008). Error-correction-based cointegration test for panel data. The Stata Journal, 8(2), 232-241.

Samuelson, P. A. (1954). The pure theory of public expenditure. The Review of Economics and Statistics, 36(4), 387-389.

Sasaki, Y. (2015). Heterogeneity and selection in dynamic panel data. Journal of Econometrics, 188(2015), 236-249.

Siddiqui, D. A., \& Ahmed, Q. M. (2013). The effect of institutions on economic growth: A global analysis based on GMM dynamic panel estimation. Structural Change and Economic Dynamics, 24(1), 18-33.

Spence, M. (2011). The next convergence. Picador, Washington.

Stiglitz, J. (1989). Market, market failures, and development. The American Economic Review, 79(2), 197-203.

Wellisch, D. (2004). Theory of public finance in a federal state. Cambridge University, Cambridge.

Westerlund, J. (2007). Testing for error correction in panel. Oxford Bullentin of Economics and Statistic, 69(6), 709-748.

\section{Appendices}

\section{Appendix A: Line trend graphs}



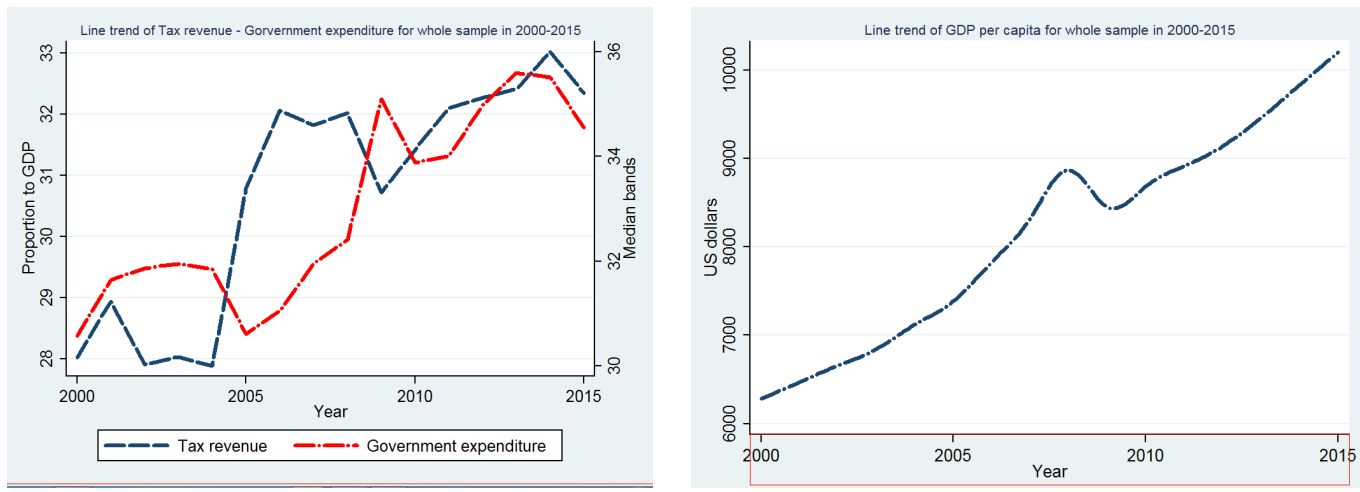

Figure 1. Line trends of tax revenue, government expenditure, and GDP per capita for the whole sample in 2000-2015
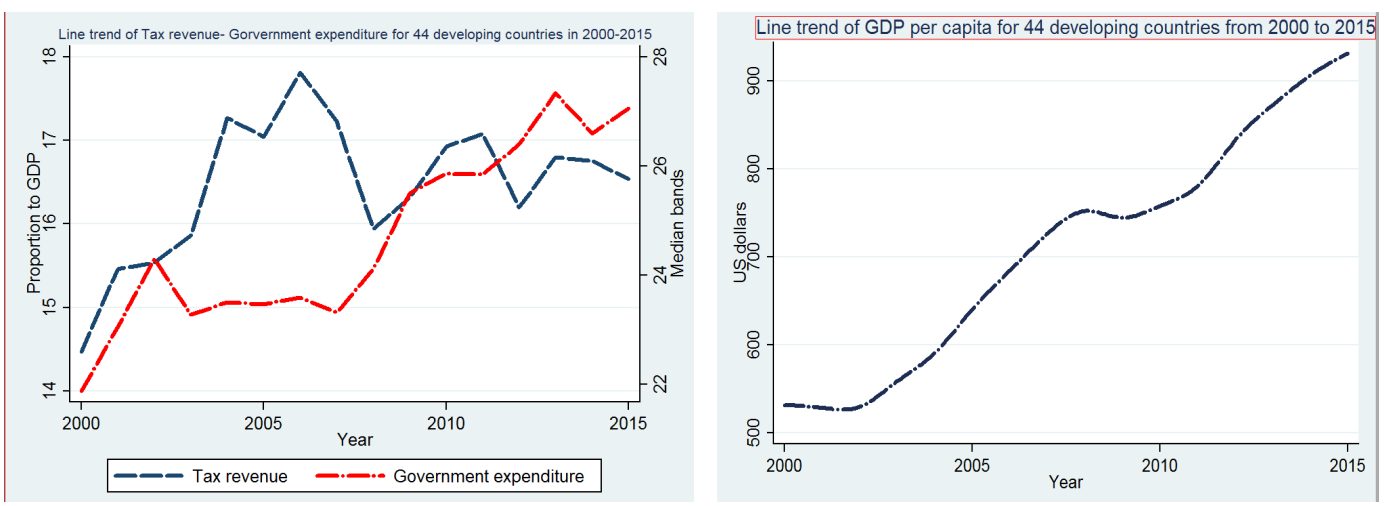

Figure 2. Line trends of tax revenue, government expenditure, and GDP per capita for 44 developing countries in 2000-2015 

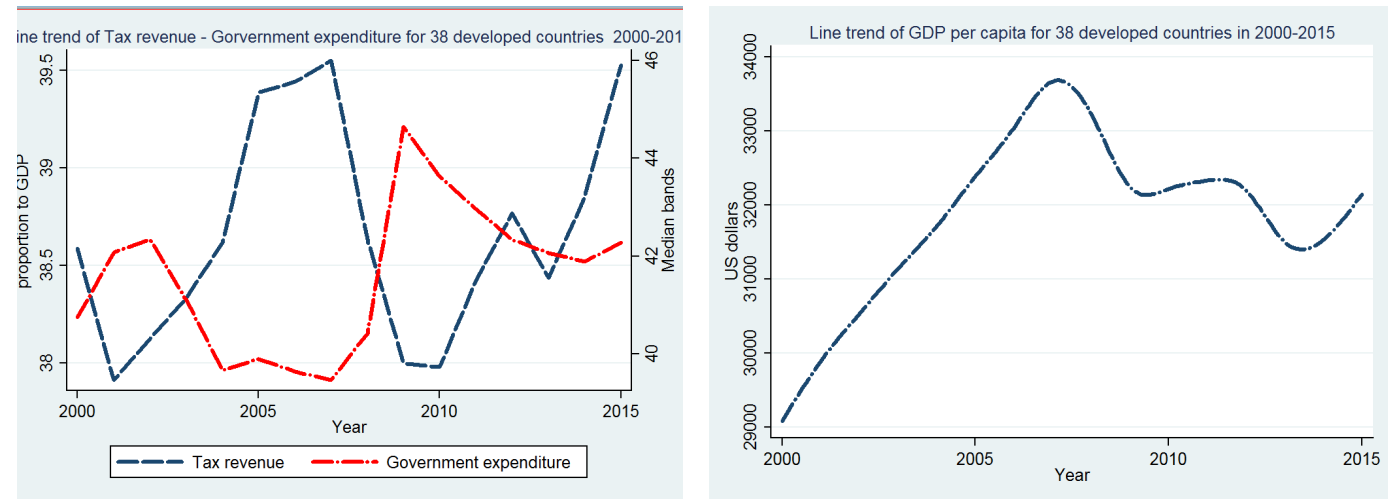

Figure 3. Line trends of tax revenue, government expenditure, GDP per capita for 38 developed countries in 2000-2015

Source: Authors' compilation using the data collected from IMF and WB

\section{Appendix B}

\section{Table B}

\section{List of studied countries}

Developed countries

\begin{tabular}{llll}
\hline Ord. & Country & Region(s) & Income group \\
\hline 1 & Australia & East Asia and Pacific & High income \\
2 & Austria & Europe and Central Asia & High income \\
3 & Belgium & Europe and Central Asia & High income \\
4 & Canada & North America & High income \\
5 & Chile & Latin America and Caribbean & High income \\
6 & Croatia & Europe and Central Asia & High income \\
7 & Cyprus & Europe and Central Asia & High income \\
8 & Czech Republic & Europe and Central Asia & High income \\
9 & Denmark & Europe and Central Asia & High income \\
10 & Estonia & Europe and Central Asia & High income
\end{tabular}




\begin{tabular}{|c|c|c|c|}
\hline 11 & Finland & Europe and Central Asia & High income \\
\hline 12 & France & Europe and Central Asia & High income \\
\hline 13 & Germany & Europe and Central Asia & High income \\
\hline 14 & Greece & Europe and Central Asia & High income \\
\hline 15 & Hungary & Europe and Central Asia & High income \\
\hline 16 & Ireland & Europe and Central Asia & High income \\
\hline 17 & Italy & Europe and Central Asia & High income \\
\hline 18 & Japan & East Asia and Pacific & High income \\
\hline 19 & Korea & East Asia and Pacific & High income \\
\hline 20 & Latvia & Europe and Central Asia & High income \\
\hline 21 & Lithuania & Europe and Central Asia & High income \\
\hline 22 & Malta & Middle East and North Africa & High income \\
\hline 23 & Netherlands & Europe and Central Asia & High income \\
\hline 24 & New Zealand & East Asia and Pacific & High income \\
\hline 25 & Norway & Europe and Central Asia & High income \\
\hline 26 & Poland & Europe and Central Asia & High income \\
\hline 27 & Portugal & Europe and Central Asia & High income \\
\hline 28 & Seychelles & Sub-Saharan Africa & High income \\
\hline 29 & Singapore & East Asia and Pacific & High income \\
\hline 30 & Slovak Republic & Europe and Central Asia & High income \\
\hline 31 & Slovenia & Europe and Central Asia & High income \\
\hline 32 & Spain & Europe and Central Asia & High income \\
\hline 33 & Sweden & Europe and Central Asia & High income \\
\hline 34 & Switzerland & Europe and Central Asia & High income \\
\hline 35 & Trinidad and Tobago & Latin America and Caribbean & High income \\
\hline 36 & United Kingdom & Europe and Central Asia & High income \\
\hline 37 & United States & North America & High income \\
\hline 38 & Uruguay & Latin America and Caribbean & High income \\
\hline
\end{tabular}

Developing countries

1 Armenia

Europe and Central Asia

Lower middle income 


\begin{tabular}{|c|c|c|c|}
\hline 2 & Bangladesh & South Asia & Lower middle income \\
\hline 3 & Belarus & Europe and Central Asia & Upper middle income \\
\hline 4 & Belize & Latin America and Caribbean & Upper middle income \\
\hline 5 & Benin & Sub-Saharan Africa & Low income \\
\hline 6 & Bolivia & Latin America and Caribbean & Lower middle income \\
\hline 7 & Brazil & Latin America and Caribbean & Upper middle income \\
\hline 8 & Bulgaria & Europe and Central Asia & Upper middle income \\
\hline 9 & Cambodia & East Asia and Pacific & Lower middle income \\
\hline 10 & Colombia & Latin America and Caribbean & Upper middle income \\
\hline 11 & Congo, Rep. & Sub-Saharan Africa & Lower middle income \\
\hline 12 & Cote d'Ivoire & Sub-Saharan Africa & Lower middle income \\
\hline 13 & Egypt & Middle East and North Africa & Lower middle income \\
\hline 14 & El Salvador & Latin America and Caribbean & Lower middle income \\
\hline 15 & Ethiopia & Sub-Saharan Africa & Low income \\
\hline 16 & Georgia & Europe and Central Asia & Upper middle income \\
\hline 17 & Ghana & Sub-Saharan Africa & Lower middle income \\
\hline 18 & Guatemala & Latin America and Caribbean & Lower middle income \\
\hline 19 & India & South Asia & Lower middle income \\
\hline 20 & Indonesia & East Asia and Pacific & Lower middle income \\
\hline 21 & Islamic Republic of Iran & Middle East and North Africa & Upper middle income \\
\hline 22 & Jamaica & Latin America and Caribbean & Upper middle income \\
\hline 23 & Kenya & Sub-Saharan Africa & Lower middle income \\
\hline 24 & Kyrgyz Republic & Europe and Central Asia & Lower middle income \\
\hline 25 & Madagascar & Sub-Saharan Africa & Low income \\
\hline 26 & Malaysia & East Asia and Pacific & Upper middle income \\
\hline 27 & Mali & Sub-Saharan Africa & Low income \\
\hline 28 & Mauritius & Sub-Saharan Africa & Upper middle income \\
\hline 29 & Moldova & Europe and Central Asia & Lower middle income \\
\hline 30 & Mongolia & East Asia and Pacific & Lower middle income \\
\hline 31 & Namibia & Sub-Saharan Africa & Upper middle income \\
\hline
\end{tabular}




$\begin{array}{llll}32 & \text { Nepal } & \text { South Asia } & \text { Low income } \\ 33 & \text { Pakistan } & \text { South Asia } & \text { Lower middle income } \\ 34 & \text { Peru } & \text { Latin America and Caribbean } & \text { Upper middle income } \\ 35 & \text { Philippines } & \text { East Asia and Pacific } & \text { Lower middle income } \\ 36 & \text { Romania } & \text { Europe and Central Asia } & \text { Upper middle income } \\ 37 & \text { Russia } & \text { Europe and Central Asia } & \text { Upper middle income } \\ 38 & \text { South Africa } & \text { Sub-Saharan Africa } & \text { Upper middle income } \\ 39 & \text { Thailand } & \text { East Asia and Pacific } & \text { Upper middle income } \\ 40 & \text { Togo } & \text { Sub-Saharan Africa } & \text { Low income } \\ 41 & \text { Tunisia } & \text { Middle East and North Africa } & \text { Lower middle income } \\ 42 & \text { Uganda } & \text { Sub-Saharan Africa } & \text { Low income } \\ 43 & \text { Ukraine } & \text { Europe and Central Asia } & \text { Lower middle income } \\ 44 & \text { Vietnam } & \text { East Asia and Pacific } & \text { Lower middle income }\end{array}$

Source: The World Bank 